Copyright (C) 2021 by Cherkas Global University

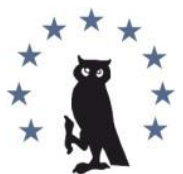

Published in the USA

Slavery: Theory and Practice

Has been issued since 2016.

E-ISSN: 2500-3755

2021. 6(1): 42-53

DOI: 10.13187/slave.2021.1.42

https://stp.cherkasgu.press

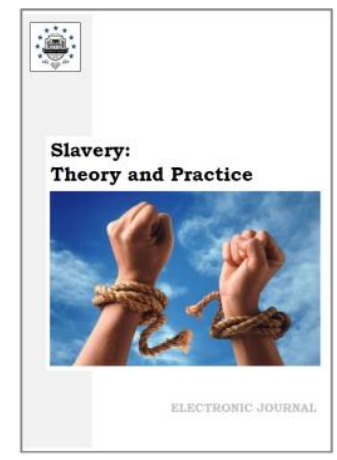

\title{
The First Artistic Experience of Comprehending the Issue of Female Sexual Slavery in Specific Don Cossack Literature: the Store «Bulavin's Grave Sin» by N.I. Krasnov (1884)
}

\author{
Artyom Yu. Peretyatko ${ }^{a}, b^{~}{ }^{*}$, Maria A. Selezneva ${ }^{c}$ \\ ${ }^{a}$ Cherkas Global University, Washington, USA \\ b Volgograd State University, Volgograd, Russian Federation \\ c Lomonosov Moscow State University, Moscow, Russian Federation
}

\begin{abstract}
The article focuses on the first artistic experience of comprehending the issue of female sexual slavery in specific Don cossack literature, particularly in the store «Bulavin's grave sin» published in 1884. Being compared with the status of the Don social thought, the story shows that N.I. Krasnov's ideas of sexual slavery reflects the other Don author's vision. On the one hand, the gravity of classical slavery and serfdom was underestimated in Don historiography (except for P.P. Sakharov); on the other hand, sympathy for women and a call for defending their rights are typical for many Don texts of the late $19^{\text {th }}$ and the early $20^{\text {th }}$ century. Therefore, a N.I. Krasnov's philippic pathos is aimed not at classical female sexual slavery, but at any form of women's subordination. A Turkish's harem into a narrative is described as a more convenient place for a heroine than the house where she lives with her legal husband. Krasnov defines the status of free women on the Don in $17^{\text {th }}$ century as «slave subordination", and he also shows that the proud and freedom-loving main heroine does not belong neither in Turkish word, nor in Russian one. Krasnov has shown, even though in slightly naïve form, immorality of female objectivization and depriving women of their right for feelings. The Krasnov's story deserves attention as the first work of literature about sexual slavery and also as an original reaction to this slavery from the liberal author who has been in times of serfdom and who was quite tolerant to it.
\end{abstract}

Keywords: female sexual slavery, fiction, gender inequality, male gaze at the status of women.

\section{1. Введение}

История специфической донской казачьей дореволюционной литературы до настоящего времени не привлекала внимания ни историков, ни филологов. Между тем литературное творчество донских авторов представляло собой достаточно любопытный феномен, связанный с попытками сконструировать собственную культурную идентичность. В 1918 г. группой казачьих интеллектуалов была даже опубликована «Донская хрестоматия» для народных школ (Донская хрестоматия, 1918). Издание было официальным: оно выходило под эгидой Всевеликого Войска Донского, а в число редакторов-составителей

\footnotetext{
* Corresponding author

E-mail addresses: ArtPeretatko@yandex.ru (A.Yu. Peretyatko), Maria.Selezneva@student.msu.ru (M.A. Selezneva)
} 
входили бывший член Государственной Думы А.И. Перовский и основатель Новочеркасского музея донского казачества Х.И. Попов (Донская хрестоматия, 1918: без страницы). Содержание книги, до сих пор специально не проанализированное, было крайне разнообразным, поскольку составители хотели и подчеркнуть принадлежность казачества к России, и познакомить юного читателя с «отличительными особенностями, выделяющими Донское войско от других частей Российского государства» (Донская хрестоматия, 1918: без страницы). Соответственно, в хрестоматии отдельными разделами были представлены и произведения русских писателей о казаках, и произведения донских авторов, и научные работы о прошлом казачества (Донская хрестоматия, 1918: I-V).

Большая часть тех ученых и литераторов, тексты которых были опубликованы в «Донской хрестоматии», в настоящее время забыта. Так, самым представленным в ней донским поэтом являлся А.А. Леонов (13 - из 61 стихотворения донских авторов, вошедших в сборник), донским историческим автором - Н.И. Краснов (3 исторических отрывка из 19), а в разделе донской прозы больше всего было произведений Ф.Д. Крюкова и И.А. Родионова (по 3 отрывка из 20) (Донская хрестоматия, 1918: II-V). Из них современной широкой публике известен, с оговорками, только Ф.Д. Крюков, которого еще в 1930 гг. назвали возможным создателем «Тихого Дона». Вероятно, забвение донской казачьей дореволюционной литературы связано с ее сравнительно невысоким художественным уровнем. Однако в плане культурном, как первый пласт авторского художественного творчества казаков о казаках, донская дореволюционная художественная литература представляет собой важнейший и недооцененный источник.

Например, в 1911 г. группа донских авторов вообще предстала перед судом (так называемое «дело донских литераторов») (Корниенко, 2013: 45). Их приговорили к различным (правда, не слишком длительным - не более года) срокам лишения свободы за незаконное распространение второго выпуска «Донского литературного сборника», содержавшего спорные художественные произведения, преимущественно об истории и текущем положении казачества (Дело донских литераторов, 1911). В судебном постановлении к числу недопустимых текстов отнесли, например, стихотворение «ИванЧига», в котором сообщалось, будто бы «со времен атамана графа Платова центр казачества был перенесен в неудобный в географическом отношении Новочеркасск, устье Дона забрали иногородние, «все у нас отвоевали и у них уже казак стал работник и батрак», Екатерина оценила армянина выше верных казаков «и казацкой войсковой наделила их землей, чтоб народ армянский рос и Донцам сел на нос» (Дело донских литераторов, 1911). Нам удалось установить, что даже некоторые стихотворения второго выпуска «Донского литературного сборника», не привлекшие внимания суда, в действительности носили одновременно политический, исторический и острокритический по отношению к имперской администрации характер. Например, басня Е.П. Савельева «Волк на воеводстве» в действительности представляла собой стихотворный памфлет против бывшего донского атамана князя Н.И. Святополк-Мирского (Перетятько, 2021: 154-171).

Важно отметить и то, что Е.П. Савельев, один из осужденных по «делу донских литераторов», был активнейшим деятелем казачьего национализма начала XX в. (Корниенко, 2013: 45). Его исследования о прошлом донских казаков, хотя и крайне сомнительны с исторической точки зрения, до сих пор изучаются как памятники донской общественной мысли (Стегленко, 2016: 66-69). И подобная ситуация, когда в качестве литератора-любителя выступал значимый общественный деятель, ученый или чиновник, для донской дореволюционной литературы была крайне характерна. Так, в «Донской хрестоматии» оказались представлены стихи крупнейшего казачьего историка В.Д. Сухорукова (Донская хрестоматия, 1918: 123-125); стихи казака-эмигранта, генерала северян во время Гражданской войны в США И.В. Турчанинова (Донская хрестоматия, 1918: 125); очерк о любимом учителе бывшего депутата Государственной Думы А.И. Петровского (Донская хрестоматия, 1918: 279-282); описание редких растений известного ботаника и географа А.Н. Краснова (Донская хрестоматия, 1918: 271-274). Таким образом, литературное творчество одиозного П.Н. Краснова, донского атамана, военного преступника и плодовитого литератора, в полной мере соответствовало специфической донской литературной традиции, в рамках которой писательство часто становилось способом 
выражения общественно-политических воззрений. Кстати, в «Донскую хрестоматию» вошли и два отрывка из произведений П.Н. Краснова (Донская хрестоматия, 1918: 258-263).

К числу важнейших авторов специфической казачьей литературной традиции относился и отец П.Н. Краснова, Н.И. Краснов. Как мы уже отметили выше, в «Донской хрестоматии» он оказался наиболее представленным в историческом разделе казачьим автором (из авторов русских столько же отрывков, правда, заметно более значительных по объему, было у знаменитого историографа Кавказской войны В.А. Потто (Донская хрестоматия, 1918: V). И именно Н.И. Краснов попытался расширить проблематику донской казачьей литературы смелым для того времени сюжетом о женском сексуальном рабстве. Главной героиней его рассказа «Тяжкий грех Булавина» является захваченная в турецкий гарем черкешенка Нина. Как нам представляется, данный текст заслуживает особого внимания если не с точки зрения его литературных достоинств, то как памятник донской общественной мысли XIX в., посвященный двум проблемам, не утратившим значения до сих пор: насильственному захвату в рабство и неравенству мужчин и женщин. Как нам представляется, интересно проанализировать обращение значимого казачьего автора к этим проблемам в рамках художественного нарратива, с одной стороны, эмоционально окрашенного, а с другой - позволяющего судить об авторском отношении к рабству не только по прямым высказываниям, но и по различным художественным деталям описания жизни в гареме. И в нижеследующей статье мы хотим как раз показать, каким Н.И. Краснов показал женское сексуальное рабство в своем рассказе.

\section{2. Материалы и методы}

Главным источником для нашего исследования стал сам рассказ «Тяжкий грех Булавина», вышедший отдельным изданием в Новочеркасске в 1884 г. (Краснов, 1884). Здесь следует отметить, что в «Донской хрестоматии» тексты Н.И. Краснова не случайно были отнесены не к прозе донских писателей, а к историческому разделу. Согласно единственной известной нам статье о Н.И. Краснове-литераторе, опубликованной в биографическом словаре «Русские писатели. 1800-1917», «стремление Краснова популяризовать донскую историю, беллетризовать малодокументированные исторические эпизоды проявилось и в немногих художественных произведениях Краснова» (Русские писатели, 1994: 132). Как мы видим, творчество Н.И. Краснова, подобно творчеству других дореволюционных донских писателей, лежало на границе с наукой и общественной жизнью, и составители «Донской хрестоматии» имели основание отнести тексты казачьего автора не к художественному, а к научно-популярному жанру.

А еще точнее было бы считать творчество Н.И. Краснова исторической публицистикой. Сам он писал в одном из своих нехудожественных текстов: «По поводу исторических исследований Дона нам делают два возражения. Зачем мы пишем историю с известной, предвзятой тенденцией? Зачем мы возводим в ореол казаков, этот тормоз русской общественной мысли? На первое мы ответим, что повествование свое мы не сочиняем и не вдаемся в фантазии, а пишем по документам, и, где можно, ссылаемся на первоклассных историков России; но действительно выбираем периоды, имеющие интерес для нынешнего времени, злобу дня, и лишь на основании прошедшего намечаем, как бы подсказываем будущее» (Краснов, 1881b: 66). Любимым же историческим периодом Н.И. Краснова было Булавинское восстание и предшествовавшие ему годы. Еще в своих ранних трудах донской автор утверждал, будто бы «донцы всегда стремились к удержанию своей сословности, и единственный факт возмущения в их истории - Булавинский бунт, когда часть казаков решилась силою оружия отстаивать свои права и преимущества» (Краснов, 1864; 210). В позднейшем же творчестве казачий историк и писатель подчеркивал, что «в то время, как Стенька Разин есть тип смелого, способного и даже гениального разбойника-пирата, а Емелька Пугачев является самозванцем, Кондратий Булавин представляет настоящий образчик бунтаря в теперешнем значении этого слова» (Краснов, 1881a: 77). При этом Н.И. Краснов, с одной стороны, писал, что восстание Булавина «имело за собой некоторое оправдание» в жестокости имперского правительства по отношению к казакам, но, с другой стороны, указывал, что как раз провал восстания хорошо иллюстрирует бесперспективность самой идеи бунта в России (Краснов, 1881a: 77). 
Учитывая подобное осовременивание Н.И. Красновым исторических событий, приближение проблематики Булавинского восстания к проблемам Российской империи второй половины XIX в., а также сравнительную ограниченность сохранившихся источников о вождях восстания, вполне понятно, почему донской автор посвятил многие свои художественные произведения этому периоду. Целый ряд прозаических текстов Н.И. Краснова, самостоятельных, но объединенных общими героями, образует своеобразный цикл, описывающий события 1680-1700 гг. В «Донскую хрестоматию» попали отрывки из самого крупного и традиционного по содержанию из этих текстов повести «Поиск донского казака Ивана Богатого под Царьград» (Донская хрестоматия, 1918: 293-305). Таким образом, «Тяжкий грех Булавина» представляет собой часть более крупного художественного полотна, посвященного проблематике русского бунта. И для того чтобы лучше понять идейное содержание данного рассказа, необходимо рассматривать его в контексте смежных текстов Н.И. Краснова.

Поэтому мы будем опираться также на повесть Н.И. Краснова «Поиск донского казака Ивана Богатого под Царьград». Эта совокупность художественных текстов, обладающих четко выраженным публицистическим пафосом, позволяет с помощью сравнительного метода точнее уяснить отношение Н.И. Краснова к рабству вообще, и к женскому в частности. В то же время, поскольку данные тексты прежде почти не изучались, а «Тяжкий грех Булавина» не исследовался вовсе, мы будем широко применять и описательный метод.

\section{3. Обсуждение}

Для донской казачьей дореволюционной литературы значимыми, хотя и не определяющими, были темы рабства (включая сюда крепостное право) и гендерного неравенства. В 1911 молодой казачий историк П.П. Сахаров издал книгу «Белое рабство на Дону», в которой писал о рабстве, захвате и перепродаже пленников как об особенности раннего казачества, не стесняясь делать такие, например, заявления: «Этот пример инстинктов и настроений известного круга расслоившегося казачества не гармонирует, конечно, с известным образом казака-друга свободы и равенства, борца за веру и народность» (Сахаров, 1911: 8-9). Соответственно, П.П. Сахаров рассматривал сперва эксплуатацию невольников, а затем крепостничество как темную сторону почти всей истории существования казачества, а других донских авторов обвинял в оправдании и даже апологии рабства. Особенно подробно он критиковал «апологета донских рабовладельцев», журналиста А.А. Карасева, в своих работах по истории донского крестьянства частично оправдывавшего казачье крепостничество его сравнительной мягкостью по сравнению с крепостничеством русским (Сахаров, 1911: 50). Однако вскоре после выхода «Белого рабства на Дону» другой донской исследователь, Е.П. Савельев, издал книгу «Крестьянский вопрос на Дону в связи с казачьим», в которой снова защищалась мысль о сравнительной мягкости донского крепостничества, и даже утверждалось, что на живущих в станицах крепостных крестьян казаки оказывали положительное влияние «живым примером свободы личности и инициативы своего труда» (Савельев, 1917: 35).

Таким образом, для большинства донских общественных деятелей второй половины XIX - начала XX вв. было характерно достаточно терпимое отношение к рабству в широком смысле этого слова, понимая под ним любую форму права собственности одного человека на другого человека. Оно, безусловно, не одобрялось, но и не рассматривалось как нечто, подлежащее безоговорочному осуждению. Безоговорочно и резко осуждались только жестокость и самовластие хозяев: например, даже Е.П. Савельев, оправдывая большинство донских хозяев крепостных, в то же время осуждал немногочисленных богатых помещиков, владевших крестьянами в Миусском и Донецких округах Земли Войска Донского, где «царили такой гнет и произвол, которые памятны и до сих пор старожилам» (Савельев, 1917: 35).

Соответственно, у Н.И. Краснова, представителя одного из богатейших и влиятельнейших донских помещичьих родов, родившегося в эпоху крепостного права, рабство как таковое трактуется относительно нейтрально. Его повесть «Поиск донского казака Ивана Богатого под Царьград» посвящена набегу казаков на турецкие владения, набегу, во время которого было освобождено множество невольников, однако эта тема в самом тексте почти не поднимается. Так, когда казаки выбирают цель набега, ни один из них не упоминает о возможном освобождении пленных христиан: всех интересует только 
добыча (Донская хрестоматия, 1918: 294-297). Само освобождение пленников описывается куда короче и спокойнее, чем военные подвиги казаков: «Казаки брали с собой лишь попадавшиеся под руку ценные вещи или освобождали христианок-невольниц и невольников. Последние, веря в сохранившиеся предания, рассчитывали на возможность подобного набега казаков и сами бежали к морю и садились в казачьи ладьи, заменяя собой убитых и утонувших казаков» (Донская хрестоматия, 1918: 299). В дальнейшем тексте упоминаний об освобожденных и их благодарности нет.

События рассказа «Тяжкий грех Булавина» происходят как раз в тот момент, когда казаки Ивана Богатого грабят турецкие предместья Царьграда и освобождают пленников. Однако этот рассказ сюжетно полностью посвящен судьбе пленной девушки-черкешенки, убитой стражем гарема. Тем не менее и в этом рассказе, где очень многочисленны авторские отступления и рассуждения, Н.И. Краснов, касаясь проблематики рабства вообще, ограничился тем, что дословно воспроизвел тот же самый текст о спасении невольников из «Поиска донского казака Ивана Богатого под Царьград» (Краснов, 1884: 20). А в финале, оценивая значение этого поиска, донской автор написал следующее: «Поиск Ивана Богатого приносил пользу России нравственным своим влиянием, подняв угасший героический дух древнего донского казачества, и указывал на возможность проявления со стороны рыцарей, представителей удали русского народа, таких неожиданных подвигов, с которыми не может считаться ни стратегия, ни тактика» (Краснов, 1884: 23). Как мы видим, ни слова о нравственном значении освобождения многочисленных пленников. Мы еще вернемся к этому сюжету, но пока просто констатируем: пафос осуждения Н.И. Краснова в рассказе «Тяжкий грех Булавина» был направлен не против рабства.

Гораздо более очевидным было негативное отношение ряда донских общественных деятелей к гендерному неравенству. Например, тот же А.А. Карасев, которого П.П. Сахаров обвинял в оправдании крепостничества, в одном из своих газетных очерков с сочувствием изображал женщину, вынужденную заниматься проституцией, чтобы прокормиться (Станько, Ахмадулин, 2002). Во втором выпуске «Донского литературного сборника», вышедшего, как мы помним, под редакцией Е.П. Савельева, оппонента П.П. Сахарова, был опубликован рассказ «Женская доля», посвященный «доле бедной исстрадавшейся женщины, лишенной по какому-то роковому недоразумению законодателем самых простых, естественных прав человека, социального положения в обществе, женщины-матери, равноправной свободной гражданки» (Донской литературный сборник, 1910: 24-37).

И в рассказе «Тяжкий грех Булавина» пафос своей обличительной критики Н.И. Краснов сосредотачивал как раз на угнетении женщины, в каких бы формах оно не проявлялось. Собственно говоря, по его мнению, положение «свободной» женщины в казачьем обществе XVII в. могло быть даже хуже, чем в турецком гареме, и это положение Н.И. Краснов прямо называл «рабским подчинением» (Краснов, 1884: 18). Донской автор эмоционально писал, что на большей части территории казачьих областей «женщина находилась в полном пренебрежении, несмотря, что нередко наравне с казаками защищала их городки от внезапных набегов татар, ногаев и калмыков» (Краснов, 1884: 18). «Встречаясь с казаком на дороге или на улице, женщина - на Дону - обязывалась сходить в сторону, показывая этим почтение и уважение даже казаку в молодом возрасте. Понятно, что, при подобных обычаях, донские казаки усвоили себе понятие, что женщина есть низшее существо, немного умнее домашнего животного», - продолжал он (Краснов, 1884: 18). Этому угнетенному положению женщин на территории большей части Войска Донского Н.И. Краснов противопоставлял ситуацию, царившую в тех округах Войска, которые граничили со Слободской Украиной, где «женщина в доме не была в рабском подчинении, напротив, пользовалась свободой и в действительности стала в положение любящей подруги, помощницы мужа» (Краснов, 1884: 18).

Данные объяснения необходимы для того, чтобы лучше понять логику характера главной героини и ее поведения в турецком гареме. Рассказ Н.И. Краснова не опирается ни на какие источники, это в полной мере художественная фантазия автора. А Н.И. Краснов не был ни великим писателем, ни выдающимся психологом, и поэтому, взявшись за сложнейшую для мужчины тему женского сексуального рабства, причем описывая ее изнутри, с позиции гаремной одалиски, он не смог добиться даже внешней психологической достоверности. Без учета времени создания и специфики донской общественной мысли 
текст Н.И. Краснова дает основания обвинить его автора в своеобразном гротеске и оправдании женского сексуального рабства. Однако на самом деле, при более внимательном анализе рассказа, становится очевидно, что Н.И. Краснов глубоко сочувствует своей героине. И в итоге рассказ «Тяжкий грех Булавина» позволяет взглянуть на женское сексуальное рабство с очень интересной точки зрения: с точки зрения человека либеральных воззрений, глубоко сочувствующего женщинам-рабыням, но при этом не просто сформировавшегося в эпоху крепостного права, но и относительно толерантного к нему.

Итак, кем же была героиня Н.И. Краснова? Нина, княжна-черкешенка, была захвачена донскими казаками при набеге на ее племя и против воли выдана за старшего брата Булавина (Краснов, 1884: 8). Тем не менее в целом у казаков ей жилось неплохо: свекровь стала для нее «приемной матерью», а к самому Булавину, еще совсем молодому холостому казаку, девушка начала испытывать нежные чувства (Краснов, 1884: 10). Однако казачьи нравы сделали ее жертвой буйного и склонного к рукоприкладству мужа. И турки похитили молодую красавицу, за которой давно следили, как раз когда она бежала от буянящего мужа в дом доброго свекра (Краснов, 1884: 8). В момент нового похищения девушка скорее обрадовалась: «ей пришло на ум, что от ненавистного мужа ее освобождает один из думников, друзей ее отрочества» (Краснов, 1884: 8). Даже осознав, что она угодила в турецкий плен, Нина не слишком опечалилась (Краснов, 1884: 10).

Всю эту предысторию Н.И. Краснов описывает не только с сочувствием, но и с очевидной симпатией к девушке. Она в его описании преподносится как обладательница «врожденной гордости, аристократической осанки, некоторого даже величия» (Краснов, 1884: 11). Муж ее, напротив, охарактеризован как «простой, безграмотный, часто пьяный казак-демократ» (Краснов, 1884: 11). Вообще, судьба Нины трактуется как типичная для черкешенки: женщины этого племени якобы были почтительны и ласковы со своими пленителями не из страха или покорности, но «от привычки видеть своих подруг и родственниц проданными в виде товара поставлявшихся гаремных красавиц» (Краснов, 1884: 9). И в итоге героиню угнетает вовсе не факт рабства, но невозможность быть с любимым, для которого она готова добровольно стать даже наложницей (Краснов, 1884: 10-11). Увы, роман с братом мужа в рамках православной казачьей культуры для Нины был невозможен в любом случае («тяжким грехом» Булавина по ходу рассказа окажутся их единственные объятия), поэтому в итоге девушка легко смирилась со своей участью стать обитательницей гарема, хотя мечтать о любимом не перестала и совершенно не стыдилась этих мыслей, несмотря на их греховность с религиозной точки зрения (Краснов, 1884: 10-11).

Жизнь Нины в гареме тоже описывается Н.И. Красновым весьма своеобразно. Уход донского автора от тем, прямо связанных с принудительным сексом вполне понятен, с учетом времени, когда создавался его текст. Однако Н.И. Краснов в принципе изображает жизнь в гареме достаточно благостно, избегая откровенно некрасивых или болезненных ситуаций. Так, захватывают черкешенку по личному желанию азовского паши, человека пожилого, и желающего заполучить красавицу не для себя, а для стамбульского чиновника, оказывавшего ему протекцию (Краснов, 1884: 9). Соответственно, в Азове Нине отводят «уютную комнату» и дают «прехорошенький черкесский наряд», а затем не мешают за вышиванием мечтать о Булавине (Краснов, 1884: 10). Ее новый владелец, Ассим-паша, охарактеризован автором как «джентльмен в частных сношениях» (Краснов, 1884: 3). Его отношения с Ниной в Стамбуле описаны без детальных подробностей, но в целом он оказывается для девушки даже терпимее мужа. Черкешенка выказывает к нему «невольную холодность» (не сознательный бунт, но нежелание угождать нелюбимому человеку) и позволяет себе «стальной, ледяной взгляд» (Краснов, 1884: 11). Однако если мужа подобное поведение приводило в бешенство, то Ассим-паша, пусть и неохотно, смирился с характером Нины. Более того, от слуг, невзлюбивших черкешенку за гордость, турок требует хотя и следить за пленницей (и казнить на месте за измену), но относиться к ней «вежливо и деликатно» (Краснов, 1884: 11). В итоге в османском гареме девушка «успокоилась» и снова «занялась любимым своим вышиванием» (Краснов, 1884: 11). Единственный раз, когда отношения Нины к турку описываются прямо, оказывается, что это «благодарность за всегдашнюю к ее капризам снисходительность» (Краснов, 1884: 13).

Таким образом, в целом сексуальное рабство в гареме Н.И. Красновым хотя и не одобряется, но описывается достаточно спокойно, как нечто лучшее, чем жизнь 
«свободной» женщины во многих казачьих станицах XVII в. Еще более рельефно это видно на примере соузниц Нины по гарему. Самым тяжелым для них является расставание с близкими: наложницы, несмотря на опасность со стороны следящих за ними евнухов, пользуются удобными случаями, чтобы «подать о себе весточку родным и милым сердцу» (Краснов, 1884: 12). Однако, в случае с черкешенками, многие женщины изначально воспитывались для гаремов: «Нравясь своему властителю, законному или незаконному мужу, адыганки получали ценные подарки золотом и драгоценностями и считали своей обязанностью, вкорененной воспитанием, делиться избытком со своими родными» (Краснов, 1884: 9). И из фактических описаний Н.И. Краснова видно, что большинство обитательниц гарема Ассима-паши жили хорошо. «Напрасно думают и пишут, что в подобном курятнике (гареме - Авт.) жилось скверно», - даже заявляет донской писатель в авторской речи (Краснов, 1884: 5). Далее он утверждает еще определеннее: «За исключением немногих, тосковавших по родине, наложницы бывали довольны выпавшей для них долей» (Краснов, 1884: 6). Правда, казачий автор не забывает уточнить, что подобное имело место именно в гареме Ассима-паши, человека порядочного и доброго, и наложницы, понимая это, если и не любили своего господина, то, по крайней мере, подобно Нине «старались ему угодить, чем могли» (Краснов, 1884: 7).

И в основном повествовании, как и в авторских рассуждениях Н.И. Краснова, пафос обличения оказывается направлен не против собственно сексуального рабства в гаремах, но вообще против такого устройства общества, в котором женщина оказывается зависима и бесправна. Интересно отметить, что здесь Н.И. Краснов, далеко не великий писатель (М.Е. Салтыков-Щедрин называл его «литератором-обывателем» (Салтыков-Щедрин, 1864: 7), попытался использовать любопытный художественный прием. Очень спокойное, объективное описание гарема Ассима-паши как едва ли не лучшего места для женщин в ту эпоху сочетается с резко экспрессивной авторской лексикой, направленной против идеи гарема как такового. Выше мы видели, что Н.И. Краснов именует этот гарем «курятником». В целом очень благожелательно описанный Ассим-паша именно как владелец гарема называется «петухом-властелином» (Краснов, 1884: 6). А работорговцы и вовсе удостаиваются наименования «продавцов нежного человеческого мяса» (Краснов, 1884: 6). Кроме того, донской автор подчеркивает, что «неверностью» гаремной наложницы, наказуемой смертной казнью, могла быть не только измена, но и «тоска по родине» или «пренебрежение к ласкам властителя» (Нине в этом отношении явно повезло) (Краснов, 1884: 6). Одалиски не имели даже подобия личных границ: «Двери спален не запирались, и безбородый сатрап мог слышать бред наложницы, затаенный вздох, подметить грустный, печальный взгляд» (Краснов, 1884: 6). И все это в сочетании с объективным описанием гарема Ассима-паши производит очень неоднозначный эффект. Как нам кажется, Н.И. Краснову удалось показать, что положение гаремных наложниц было недопустимым в нормальном обществе не из-за плохого обращения с ними, но из-за того, что женщина в гареме лишалась права свободно выражать - или, точнее, вообще иметь - свои собственные чувства, объективизировалась в качестве инструмента для удовлетворения потребностей «петуха-властелина». В то же время в контексте общества XVII в. подобное сексуальное рабство было нормальным, поскольку права женщины большинством мужчин отрицались в принципе, и роль наложницы в гареме терпимого и доброго Ассима-паши все же давалась гордой и внутренне свободной Нине легче роли официальной жены буйного мужа-казака. Возможно, донской автор осознанно хотел вызвать у читателя ужас перед реальностью, в которой положение женщины было настолько безнадежно, что гарем оказывался предпочтительнее законного брака.

Поведение гаремных девушек, одалисок, тоже было описано Н.И. Красновым как психологически сложное, что вообще-то для его творчества не слишком характерно. Как мы видели выше, одалиски Ассима-паши в целом были вполне довольны своей судьбой и пытались угождать господину. Тем не менее многие из них мечтали о романе на стороне, с мужчиной, который бы действительно им нравился: «Если в действительности случалось мало романтических приключений, то, без сомнения, головка каждой хорошенькой одалиски ими была наполнена гораздо более, чем упражнениями в музыке и танцах» (Краснов, 1884: 7). Донской автор не осуждает подобное двуличие и не указывает случаев открытого бунта гаремных девушек против несправедливого общества. Судя по всему, с его 
точки зрения, мечты о романтических приключениях были для одалисок естественным и относительно безопасным способом облегчить свое положение, внешне комфортное, но предполагавшее отказ от свободы собственных чувств. Объективизация девушек, лишение их права на чувства в описании Н.И. Краснова привели только к тому, что даже внешне покорные гаремные одалиски начали внутренне протестовать в единственно доступной им форме. И этот протест донской автор описывал с большей симпатией, чем пустые развлечения одалисок.

В принципе, схожим образом ведет себя и Нина, с тем исключением, что честная и гордая черкешенка неспособна угождать нелюбимому человеку против своей воли: «Она верила в свое предопределение и чего-то постоянно надеялась, но эта тайная надежда в душе ее соединялась с каким-то внутренним, инстинктивным страхом: она шептала молитвы, обращаясь мысленно к Господу Богу, и успокаивалась» (Краснов, 1884: 12). Понятно, что оставшийся на Дону Булавин для Нины - недостижимая мечта, прямое признание в любви к нему обернется для девушки смертной казнью, и ей остается только «сильно, страстно» думать о «многом и многом» (Краснов, 1884: 11). При этом Нина, как будет видно из дальнейшего текста, достаточно смела и готова на многое пойти ради своей мечты, но в гареме Ассима-паши у нее просто нет иного будущего, кроме как продолжать обслуживать своего «петуха-властелина» или умереть.

Ситуацию неожиданно резко меняет сам Ассим-паша, продолжая объективизацию Нины. Дело в том, что его доброта к девушке связана не только с хорошим характером: турок является опытным царедворцем, «экс-министром», и черкесская красавица для него еще и ценный ресурс для подарков (Краснов, 1884: 14). И снова Н.И. Краснов избегает намеренного обострения темы: Ассим решает подарить Нину брату султана, который, по известным черкешенке слухам, «очаровательный юноша» (Краснов, 1884: 12). Прямо реакция Нины на эту новость не описана, но, по словам евнухов, она «встречает известие с радостью» (Краснов, 1884: 12). Интересно, что в тексте вовсе не озвучивается мысль о том, что эта радость могла бы быть связана с надеждой Нины сбежать из менее охраняемого гарема. Представлены только рассуждения Ассима, уверенного, что «честолюбие взяло свое» и гордой черкешенке хочется стать принцессой, а в перспективе и императрицей (Краснов, 1884: 12).

Если до этого момента повествование Н.И. Краснова развивалось очень размеренно и сюжетно, было малонасыщенным (самые важные моменты вообще передавались через косвенную авторскую речь), то после решения отдать Нину брату султана меняется сам стиль текста: теперь это прямое описание событий с многочисленными диалогами. Сначала единственный раз в рассказе прямо описана попытка сексуального насилия со стороны Ассима-паши. Черкешенка готова к отправке в другой гарем, и турок напоследок осматривает ее, причем делает это предельно вежливо, даже снимает с девушки одежду с извинениями (Краснов, 1884: 13). Нина, действительно благодарная доброму хозяину, не удерживается от легкого кокетства (Краснов, 1884: 13). И Ассим-паша, прежде отказавшийся от холодной к нему красавицы, увидев подобный знак внимания с ее стороны, резко изменил свое мнение: «Думая, что Нина, подобно другим наложницам, стала ласковой и приветливой за присланные ей утром дорогие подарки, и, восхитившись ее чудной красотой, Ассим-паша мгновенно, как истый турок и гаремный властелин, вспыхнул неудержимой страстью» (Краснов, 1884: 14). Как мы видим, даже для доброго и гуманного Ассима-паши внимание девушки могло быть только реакцией на подарки, а легкое кокетство и ласковое обращение являлись недвусмысленными выражениями готовности к сексу, т.е. чувства девушки определялись за нее желаниями мужчины. Впрочем, для нарратива Н.И. Краснова характерно, что даже в подобной ситуации Ассим повел себя относительно достойно и чрезмерно романтично: хотя он, истолковав кокетство Нины как внимание к нему, и решил взять ее немедленно, но, понимая гордость княжны, одновременно турок обещал, что распустит остальной гарем, оставит черкешенку единственной женой и уберет следящих за ней евнухов (Краснов, 1884: 14).

Трудно сказать, как конкретно отреагировала бы Нина на подобное предложение, значительно улучшающее ее положение и дающее шанс сбежать (впрочем, турок собирался взять ее в любом случае, а ей самой его объятия были неприятны), но как раз в этот момент на резиденцию Ассима-паши напали казаки Ивана Богатого (Краснов, 1884: 14). И Нина 
ощутила не страх, но лихорадочное возбуждение: для девушки одна возможность увидеться с Булавиным была дороже роскошной и комфортной жизни в гареме с любящим турком. «Лишь бы на одно мгновение его, моего ненаглядного Кондратия, увидеть, а там хоть смерть, мне все равно», - подобную мысль черкешенки Н.И. Краснов озвучивает совершенно прямо (Краснов, 1884: 15). Таким образом, мы в очередной раз убеждаемся, что для Нины тяжело было не рабство как таковое, но невозможность выражать свои чувства к любимому, и она прекрасно понимала бесперспективность своей любви как в османском, так и в русском мире, но была готова хотя бы умереть рядом с Булавиным.

Собственно говоря, дальше происходит именно это. Реализация художественных замыслов Н.И. Краснова часто была не вполне удачной: собственно говоря, уже сцена Ассима с Ниной, хотя и задумывалась эротической, описана довольно безвкусно, с оборотами вроде «грудь, дышащая ароматом здоровья» (Краснов, 1884: 13). Однако замысел финальной сцены с Ниной по-своему красив и символичен. На смену Ассиму-паше, убежавшему защищать свою резиденцию, появляется Булавин, идущий освобождать невольниц (кстати, его мотивация к этому описана как «казачий обычай», и явного сочувствия к пленницам он не выказывает) (Краснов, 1884: 16). Нина, увидев его, смело и страстно бросается в объятия любимого, признаваясь ему во всем (Краснов, 1884: 16-17). Но, хотя Кондратий и отвечает ей взаимностью, в комнату с разных сторон входят хранители культурных традиций двух миров: евнух - страж гарема и фанатичный старообрядец Игнат Некрасов (Краснов, 1884: 17). Для них происходящее, выражение девушкой свободной любви, равно неприемлемо, хотя и по разным причинам: для евнуха это была измена наложницы Ассаму-паше, а для Некрасова - измена черкешенки мужу с его собственным братом. И евнух, и Некрасов хотели застрелить не замечающих их влюбленных, но турок успел выстрелить из двуствольного пистолета первым, убив Нину и ранив Булавина, после чего суровый воин Некрасов среагировал мгновенно: своим выстрелом он убил наповал не раненого товарища, а евнуха (Краснов, 1884: 17-18).

Эта сцена доводит до логического конца обличительный пафос рассказа Н.И. Краснова. Не желающей предавать свою любовь, Нине нет места в гареме, но нет ей места и в «свободном» казачьем обществе. И освобождение из гарема доброго Ассима-паши оборачивается для девушки смертью. Более того, хотя Некрасов в итоге не рассказывает о свершившемся на его глазах «грехе», казаки демонстрируют полное равнодушие к убитой невольнице, «как будто на диване лежала дохлая кошка» (Краснов, 1884: 20).

\section{4. Заключение}

И нам остается констатировать, что, вводя в круг тем дореволюционной казачьей литературы сюжет о женском сексуальном рабстве, Н.И. Краснов в полном соответствии с тенденциями донской общественной мысликонцентрировал внимание на недопустимости угнетения женщины, а не на аморальности рабства как такового. Более того, гарем Ассимапаши в его рассказе описан скорее позитивно как удобное и комфортное место для большинства женщин. В принципе осуждая саму идею «торговли нежным человеческим мясом», донской писатель показал, что в гареме доброго и терпимого турка героине было лучше, чем в доме законного мужа, тоже взявшего ее силой, но при этом еще и допускавшего рукоприкладство.

Пафос критики Н.И. Краснова был направлен не на формальное рабство, юридическую принадлежность гаремной невольницы хозяину, но на самое общество, допускающее женское бесправие. Более того, гаремных одалисок донской писатель даже не называет рабынями, зато говорит о «рабском подчинении» женщин в большинстве казачьих станиц. При этом самое рабство Н.И. Краснов описывает довольно мягко, что тоже вообще характерно для донской общественной мысли. Ассиму-паше даже удалось растопить сердце своей гордой пленницы терпимостью к ее капризам, причем растопить не как любовнику (в этом качестве он остается Нине неприятен), но как хорошему, в сущности, человеку. Однако как раз из «Тяжкого греха Булавина» видно, что Н.И. Краснова нельзя обвинить в оправдании рабства. Донской автор фактически выступал за его объективную оценку, показывая, что сравнительно с некоторыми другими формами организации общества формальное рабство было даже предпочтительнее. Но при этом всю жизнь демонстрировавший либеральные взгляды Н.И. Краснов убедительно доказал, что даже 
самое мягкое рабство у доброго хозяина ужасно именно отсутствием свободы выбора, невозможностью самостоятельно определять свою судьбу. И описание жестокостей рабства только отвлекло бы от основного пафоса его рассказа. Это тема для отдельного исследования, но просто отметим, что сама свобода Нины осмысляется Н.И. Красновым через категорию любви, а рабство - через категорию, пускай и относительно мягкого, изнасилования. И Нина мечтает пусть даже умереть, но свободной и рядом с любимым, но не жить в комфортном рабстве - и автор ей в этом явно сочувствует.

Важно понимать еще и то, что идея борьбы с угнетением женщин для времени написания рассказа Н.И. Краснова была куда более актуальной, чем идея борьбы с рабством. Донской писатель в очередной раз выступал в своем тексте не столько как художник, сколько как общественный деятель, выбрав тему, «имеющую интерес для нынешнего времени, злобу дня» и «на основании прошедшего наметив, как бы подсказав будущее». В художественном отношении текст Н.И. Краснова, безусловно, слаб, однако он заслуживает внимания и уважения как выражение гражданской позиции. А главная идея донского писателя не устарела и в наши дни: даже формальное рабство у доброго и гуманного хозяина может быть куда менее страшным, чем «рабское подчинение» формально свободной женщины в традиционном обществе.

\section{Литература}

Дело донских литераторов, 1911 - Дело донских литераторов // Старые донские дороги Евграфа Савельева [Электронный ресурс]. URL: https://www.passion-don.org/writer/dov-1911245.html (дата обращения: 29.08.2021).

Донская хрестоматия, 1918 - Донская хрестоматия. Новочеркасск, 1918. 406 с.

Донской литературный сборник, 1910 - Донской литературный сборник. Вып. II. Новочеркасск, 1910. $272 \mathrm{c.}$

Корниенко, 2013 - Корниенко Б.С. Правый Дон: казаки и идеология национализма (1909-1914). СПб., 2013. 232 с.

Краснов, 1864 - Краснов Н.И. Военное обозрение Земли Войска Донского. СПб., 1864. $352 \mathrm{c}$.

Краснов, 1881a - Краснов Н.И. Исторические очерки Дона. От Разина до Булавина // Русская речь. 1881. № 1. С. 76-102.

Краснов, 1881b - Краснов Н.И. Исторические очерки Дона. Борьба Чернышева с войсковыми атаманами // Русская речъ. 1881. № 5. С. 66-93.

Краснов, 1884 - Краснов Н.И. Тяжкий грех Булавина. Новочеркасск, 1884. 24 с.

Перетятько, 2021 - Перетятько А.Ю. Интерпретация атаманства Н.И. СвятополкМирского в басне Е.П. Савельева «Волк на воеводстве» // Новое прошлое / The New Past. 2021. № 1. С. 154-171.

Русские писатели, 1994 - Русские писатели. 1800-1917. Т. 3. М., 1994. 610 с.

Савельев, 1917 - Савельев Е.П. Крестьянский вопрос на Дону в связи с казачьим. Новочеркасск, 1917. 80 с.

Салтыков-Щедрин, 1864 - Салтыков-Щедрин M.E. Литературные мелочи // Современник. 1864. № 5. С. 1-26.

Сахаров, 1911 - Сахаров П.П. Белое рабство на Дону. К 50-й годовщине освобождения донских крестьян. Новочеркасск, 1911. 52 с.

Станько, Ахмадулин, 2002 - Станько А.И., Ахмадулин Е.В. Зарождение частной прессы на Дону // Relga. 2002. №6 (84). [Электронный pecypc]. URL: http://www.relga.ru/ Environ /WebObjects/tgu-www.woa/wa/Main?textid=134\&level1=main\&level2=articles (дата обращения: 29.08.2021).

Стегленко, 2016 - Стегленко Е.В. Е.П. Савельев о взаимоотношениях русских властей и войска донского и инкорпорации казачества в состав России // Известия высших учебных заведений. Северо-Кавказский регион. Общественные науки. 2016. № 1 (189). С. 66-69.

\section{References}

Delo donskikh literatorov, 1911 - Delo donskikh literatorov [The case of the Don writers] // Old Don roads of Evgraf Savelyev [Electronic resource]. URL: https://www.passion-don.org/ writer/dov-1911-245.html (date accessed: 29.08.2021) [in Russian]. 
Donskaya khrestomatiya, 1918 - Donskaya khrestomatiya [Don chrestomathy]. Novocherkassk, 1918. P. 406. [in Russian]

Donskoi literaturnyi sbornik, 1910 - Donskoi literaturnyi sbornik [Don literary collection]. Vol. II. Novocherkassk, 1910. P. 272. [in Russian]

Korniyenko, 2013 - Korniyenko, B.S. (2013). Pravyj Don: kazaki i ideologija nacionalizma (1909-1914). [Right Don Cossacks and the Ideology of Nationalism (1909-1914)]. SPb. P. 232. [in Russian]

Krasnov, 1864 - Krasnov, N.I. (1864). Voennoe obozrenie Zemli Donskogo Voiska [Military review of the Don Host Oblast]. SPb. P. 352. [in Russian]

Krasnov, 1881a - Krasnov, N.I. (1881). Istoricheskie ocherki Dona. Ot Razina do Bulavina [Historical sketches of the Don. From Razin to Bulavin]. Russkaya rech'. 1: 76-102. [in Russian]

Krasnov, 1881b - Krasnov, N.I. (1881). Istoricheskie ocherki Dona. Bor'ba Chernysheva s voiskovymi atamanami [Historical sketches of the Don. Chernyshev's fight against atamans of Don Host]. Russkaya rech'. 5: 66-93. [in Russian]

Krasnov, 1884 - Krasnov, N.I. (1884). Tyazhkii grekh Bulavina [Bulavin's grave sin]. Novocherkassk. P. 24. [in Russian]

Peretyatko, 2021 - Peretyatko, A.Yu. (2021). Interpretation of the rule of N.I. SvyatopolkMirsky in the fable by E.P. Savelyev "The Wolf in the Voivodeship". Novoe proshloe/The New Past. 1: 154-171. [in Russian]

Russkie pisateli, 1994 - Russkie pisateli. 1800-1917 [Russian Writers. 1800-1917.]. Vol. 3. M., 1994. P. 610. [in Russian]

Savel'ev, 1917 - Savel'ev, E.P. (1917). Krest'yanskii vopros na Donu v svyazi s kazach'im [Peasant matter on the Don in relation to Cossack]. Novocherkassk. P. 80. [in Russian]

Saltykov-Shchedrin, 1864 - Saltykov-Shchedrin, M.E. (1864). Literaturnye melochi [Literary trifles]. Sovremennik. 5: 1-26. [in Russian]

Sakharov, 1911 - Sakharov, P.P. (1911). Beloe rabstvo na Donu. K 50-i godovshchine osvobozhdeniya donskikh krest'yan [White slavery on the Don. To 50th anniversary of the Don peasants' emancipation]. Novocherkassk, 52 p. [in Russian]

Stanko, Akhmadulin, 2002 - Stanko, A.I., Akhmadulin, E.V. (2002). Zarozhdenie chastnoi pressy na Donu [The emergence of a private press on the Don]. Relga. 6 (84). [Electronic resource]. URL: http://www.relga.ru/Environ/WebObjects/tgu-www.woa/wa/Main?textid=134\& level1=main\&level2=articles (date of access: 29.08.2021). [in Russian]

Steglenko, 2016 - Steglenko, E.V. (2016). E.P. Savel'ev o vzaimootnosheniyakh russkikh vlastei i voiska donskogo i inkorporatsii kazachestva v sostav Rossii [E.P. Savel'ev on the relationships of Russian government and the Don Host and the incorporation of Cossacks into Russia]. Izvestiya vysshikh uchebnykh zavedenii. Severo-Kavkazskii region. Obshchestvennye nauki. 1(189): 66-69. [in Russian]

\title{
Первый опыт осмысления женского сексуального рабства в донской казачьей литературе: рассказ «Тяжкий грех Булавина» Н.И. Краснова (1884)
}

\author{
Артем Юрьевич Перетятько a , b , Мария Антоновна Селезнева ${ }^{c}$ \\ а Черкас глобальный университет, Вашингтон, США \\ b Волгоградский государственный университет, Волгоград, Российская Федерация \\ c Московский государственный университет им. М.В. Ломоносова, Москва, \\ Российская Федерация
}

Аннотация. Статья посвящена первой попытке художественного осмысления женского сексуального рабства в специфической донской казачьей литературе (в рассказе «Тяжкий грех Булавина» Н.И. Краснова, опубликованном в 1884 г.). На основе

\footnotetext{
* Корреспондирующий автор

Адреса электронной почты: ArtPeretatko@yandex.ru (А.Ю. Перетятько), Maria.Selezneva@student.msu.ru (M.А. Селезнева)
} 
сопоставления текста рассказа с ситуацией в донской общественной мысли показано, что представления Н.И. Краснова о положении женщины в сексуальном рабстве отражали настроения других донских авторов. С одной стороны, тяжесть классического рабства и крепостной зависимости в донской историографии (за исключением П.П. Сахарова) преуменьшалась; с другой стороны, для многих донских текстов конца XIX - начала XX вв. характерны сочувствие к женщинам и призывы бороться за их права. Соответственно, и Н.И. Краснов направляет свой обличительный пафос не против классического женского сексуального рабства в гареме, но против любой формы бесправного подчинения женщины мужчине. В его нарративе гарем турка Ассима-паши описан как более комфортное для героини место, чем дом, где она живет в законном браке с мужем-буяном. Статус свободных женщин на Дону в XVII в. Н.И. Краснов определяет как «рабское подчинение» и показывает, что гордой и свободолюбивой главной героине нет места ни в турецком, ни в русском мире. Пускай и в несколько наивной форме, но Н.И. Краснов показал аморальность объективизации женщин, лишения их права на собственные свободные чувства. Рассказ Н.И. Краснова заслуживает внимания и как первое произведение донской региональной литературы о сексуальном рабстве, и как взгляд на это рабство с оригинальной точки зрения либерального автора, сформировавшегося при крепостном праве и достаточно толерантного к последнему.

Ключевые слова: женское сексуальное рабство, художественная литература, гендерное неравенство, положение женщин глазами мужчин. 